Harkness Scholarship in 1906, having been a demonstrator in geology since 1904, and in 1906 also he entered the Geological Survey by competitive examination. For a time he worked in the Midland coalfields districts under Lamplugh, but he surveyed also in North Wales. When the Great War broke out he devoted much time to the study of British iron ores, on which subject he ultimately became a recognized authority; but he also gave much assistance to the Ministry of Munitions on many other subjects connected with British resources of economic minerals.

In 1920 Smith was appointed district geologist, and shortly thereafter proceeded to Whitehaven where he superintended the revision of the geological maps of the Cumberland coalfield and adjacent districts. He had already produced a notable monograph on the Cumberland hrmatite iron ores which soon passed into a second and revised edition, and is the standard work on that subject. The Cumberland coalfield is very complex in structure and was not well understood before the revision undertaken by Bernard Smith and his staff; but it may be said that it is now one of the best known British coalfields, and the new maps and memoirs leave nothing to be desired. His work in that district was much appreciated by the local engineers and mine owners, and his personal relations with all connected with the industry, even though they might differ from him in opinion, were always excellent.

In 1931 Dr. Smith succeeded Mr. John Allen Howe as assistant to the Director in London and was placed in charge of all the field work in England. He also arranged the North Wales exhibits in the new Museum of Practical Geology. His time was now principally occupied in administrative work, and in answering inquiries sent in by Government departments and by the public. In this respect he was a great success, and in due course he succeeded to the directorship of the Survey and Museum in October, 1935.

Smith's natural bent to field geology was shown by his text-book of "Physical Geography" (A. and C. Black, Ltd.) now in its third edition. He also wrote on the glaciation of the Lake District and of the Isle of Man and on the history of Cumbrian rivers. His official work was very varied, but his principal contributions to Survey literature were his "Iron Ores of Cumberland" and the memoirs on the Whitehaven coalfield which he edited and in large part compiled. $\mathrm{He}$ was awarded the degree of Sc.D. (Cambridge) in 1924, and the Bigsby Medal of the Geological Society in 1927. The Royal Geological Society of Cornwall conferred on him the Bolitho Medal in 1933. In 1933 he was elected fellow of the Royal Society, and he served on the Council. In 1935 he delivered the Cantor Lectures on "Underground Water Supply" at the Royal Society of Arts ; and he was actively engaged in the work of the Inland Water Resources Committee of the Ministry of Health. He served also on the National Committee of the Union of Geodetics and Geophysies and was a member of the Sub-Committee on Vulcanology and Hydrology.

\section{Dr. H. A. D. Jowett}

IN a characteristic appreciation of the late Sir Henry Wellcome, published in The Times of August 3, Prof. H. E. Armstrong points out that he chose his men with great shrewdness. It is with great regret that we have to record, so soon after the loss of Sir Henry Wellcome himself, the death of one of these chosen helpers, as the result of a motor accident on Monday, August 10. Dr. Jowett was born at Dorchester in 1870 , but received his education at the Royal Grammar School, Lancaster, and re. mained in that town until 1891, when he gained a Bell Scholarship offered annually by the Pharmaceutical Society and became a student in the Society's College in Bloomsbury Square. He took his diploma in due time, along with most of the College prizes, and was awarded the Redwood Scholarship, which gave him entry to the Society's Research Laboratories, where he remained until 1896, working on aconitine and atisine, the latter being the subject of the thesis which he presented successfully for the London D.Sc.

In that year, Jowett became chief assistant in the newly-founded Wellcome Chemical Research Laboratories. There he spent ten busy and fruitful years, during which he made contributions of the first importance to our knowledge of the chemistry of the alkaloid pilocarpine, the hormone adrenaline and some of the naturally occurring glycosides and anthraquinone derivatives, chrysophanic acid, emodin and aloin. The work on pilocarpine and adrenaline was not only important in itself, but also it stimulated interest in the glyoxaline nucleus and in pressor amines, subjects which were to occupy both chemists and pharmacologists in the Wellcome Laboratories for some years to come. Jowett also began during this period those interesting investigations on the effect of change in structure in the tropeines on their mydriatic action.

In 1906 Jowett left London for Dartford to inaugurate the Experimental Department of the Wellcome Chemical Works, and a year later was appointed works manager, but was still able for some years to continue with collaborators the researches started in London. Having acquired a considerable reputation as an investigator, Jowett must have accepted his new post with some misgivings, but he soon justified his choice, and under his management the manufacture of fine pharmaceutical chemicals increased slowly but surely, and when War broke out in 1914 the works were ready to take a great part in the manufacture of those essential synthetic drugs which the nation had up to that time been content to import. In a very short time British equivalents for such complex drugs as 'salvarsan' and 'neosalvarsan' were being manufactured, and numerous other fine chemicals were added as required.

This development has continued steadily to the present time, and in this connexion it is only necessary to refer to the rapidity with which the manufacture of new products, such as insulin, ephedrine and ergometrine, has been undertaken and to the successful research work on cardiac glucosides and ergot 
alkaloids now in progress in the experimental laboratories at Dartford, to show that his inspiring personality was as vigorous as ever after forty years service to the Wellcome Foundation.

Dr. Jowett was not only skilled in chemistry, administration and the management of men: he became a motorist almost as soon as motor-cars were available; he was a keen golfer and an enthusiastic Wagnerian, and in recent years he developed a great interest in local government, becoming a member of the Dartford Borough Couneil, where as chairman of the Health Committee his administrative experience and scientific knowledge were of great service to his fellow citizens.

Dr. Jowett's friends are not likely to forget his achievements, but they will remember even more vividly his kindly and lovable personality.
WE regret to announce the following deaths:

Prof. F. Breinl, professor of hygiene in the German University of Prague, an authority on bacteriology, on July 29.

Prof. B. G. Cormack, emeritus professor of botany in the Anderson College of Medicine, Glasgow, on August 19, aged seventy years.

Dr. W. G. Plummer, assistant keeper in the Science Division (Physics and Geophysics) of the Science Museum, South Kensington, on August 2, aged thirty-eight years.

W. Rintoul, O.B.E., a director of research of Imperial Chemical Industries, Ltd., formerly manager of the Ardeer factory of Nobel's Explosives Co. Ltd., on August 24, aged sixty-six years.

\section{News and Views}

\section{Synthesis of Vitamin $B_{1}$ (Antineurin)}

SINCE the realization that the molecule of vitamin $B_{1}$ contains two heterocyclic rings, a substituted pyrimidine and a substituted thiazole, intensive research has been directed towards establishing the positions of the substituent groups and the method of combination of the two rings. According to a paper of which a brief abstract appears on p. 372 of this issue, Prof. Williams and his collaborators at Columbia University have now succeeded in isolating a compound which is chemically and physiologically identical with the natural vitamin. Several groups of workers in Great Britain and Germany have been working at the same problem, but they will doubtless be among the first to congratulate the American chemists concerned on a brilliant and important piece of organic synthesis. It may be noted that this achievement means that, with the syntheses of ascorbic acid, lactoflavin, vitamin $D$ and vitamin $B_{1}$, four vitamins have now been produced from completely inactive organic reagents by purely chemical means.

\section{New Fossil Anthropoid Skull from South Africa}

A DIScovery is announced from South Africa which, if first impressions are confirmed by more detailed examination, may go far towards clearing up a point which has been a matter of acute anthropological controversy for more than a decade. Dr. Robert Broom, of the Transvaal Museum, and his colleagues, it is reported in a dispatch from the Johannesburg correspondent of The Times in the issue of August 26, have discovered in the Sterkfontein caves near Krugersdorp, a natural cast in limestone of the brain of an advanced type of ape and number of fossilized bones of the skull, including jaws and teeth. It is anticipated that this new evidence will prove of importance in its bearing upon the status of the phylogeny of man and the great apes, and more especially on the position of the Taungs skull. It will be remembered that, when that fossil was found in 1924, some doubt was expressed as to how far the approximation to the human type in its characters stressed by Prof. Raymond Dart, by whom it was discovered, was due to its immaturity. The young of the chimpanzee, it was pointed out, is well known to exhibit pseudohuman characters, which disappear as maturity approaches; and it was agreed that the Taungs skull was that of an individual of not more than six years of age. As the Sterkfontein specimen, it would appear, is adult, a comparison with the Taungs skull may determine these uncertainties, and at the same time afford an indication of the relation of these fossil types to existing anthropoids as well as to early forms of man.

\section{Roman Leicester-a National Asset}

The fate of Roman Leicester, which now hangs upon the decision of the City Council, is a problem in which the nation is no less deeply concerned, though from a slightly different point of view, than the city itself. A site in the heart of the city's oldest relies, purchased at a cost of $£ 24,000$ for the erection of public baths, has yielded on excavation remains of the Roman period, more particularly of the forum, the centre of municipal life, which in certain respects are unique (see Nature of July 11, p. 69). While on one hand the local authority may allow due weight to the advantage to Leicester in the possession of this unique and irreplaceable monument of the past, yet local pride must inevitably be tempered by a sense of the duty of trustees of public funds; on the other hand the nation at large is a custodian of such treasures as this for the benefit not only of contemporary archæological studies, but also of posterity. The most meticulous records of excavation, however valuable for scientific study, cannot take the place of relics 